\title{
AN ANALYSIS OF SOME ANTHROPOMETRIC AND PHYSICAL PARAMETERS OF CHILDREN RELATED TO AGE ${ }^{1}$
}

\section{ÇOCUKLARIN BAZI ANTROPOMETRIKK VE FIZIKKSEL PARAME- TRELERE AİT DEĞERLERINIIN YAŞLARA GÖRE İNCELENMESI}

\author{
Gökhan DELICEEOĞLU $U^{1}$ Deniz KAMILLÖ̆LU \\ ${ }^{1-2}$ Kırıkkale University, Faculty of Sport Science, Kirtkkale / Turkey
}

ORCID ID: 0000-0003-2459-9209', 0000-0003-4139-4985 ${ }^{2}$

Öz: Amaç: Bu çalışmanın amacını 4-13 yaş aralığındaki spor yapan çocukların bazı antropometrik ve fiziksel parametrelerinin yaş ve cinsiyete göre incelenmesi oluşturmaktadır. Yöntem: Araştırma grubunu Ankara ilinde ilköğretim okullarına ve özel spor merkezlerine devam eden 4-13 yaş aralı̆̆ında, 200 kız ve 429 erkek olmak üzere, toplam 629 spor yapan çocuktan oluşmaktadır. Araştırma grubuna sırasıyla, bazı antropometrik ölçümler ve kavrama kuvveti, esneklik, dikey sıçrama, durarak uzun atlama, durarak sağlık topu atışı1,10m-20m. sürat koşusu ve çabukluk testleri uygulanmıştır. Antropometrik ve Fiziksel parametrelere ait verilerin ortalama ve standart sapma değerleri bulunmuştur. Bulgular: Araştırma grubuna uygulanan durarak uzun atlama, el pençe, dikey sıçrama ve sağlık topu atma kuvvet testlerinde bazı yaş grupları dışında erkeklerin kızlardan daha yüksek değerlere sahip olduğu görülmektedir. Esneklik değerlerine göre 6 yaşına kadar yakın değerler gözlenirken, bu yaştan itibaren kız çocukların daha yüksek esneklik değerlerine sahip olduğu belirlenmiștir. Sürat yetileri incelendiğinde birçok yas grubunda erkek çocukların daha düşük sürat değerlerine sahip olduğu belirlenmiştir. Çabukluk yetisinde ise bütün yaş gruplarında erkek çocukların daha düşük sürelere sahip olduğu belirlenmiş̧ir. Elde edilen bulgulara göre 4-13 yaş grubu çocukların antropometrik özelliklerinin fiziksel gelişimine bağlı olarak artı̧̧ gösterdiği söylenebilir. Motorik özellikler incelendiğinde yaş gelişime bağlı olarak 10 yaşına kadar erkek ve kızların gelişimlerinin benzer olduğu görülmektedir. Ancak kas yapısına bağlı olarak erkeklerin kuvvet, sürat ve çabukluk gerektiren alanlarda 10 yaşından sonra kızlara göre daha fazla gelişim gösterdiğini söylenebilir. Sonuç: Sonuç olarak bazı parametrelerin yașa ve cinsiyete bağlı olarak artışlar gösterdiği belirlenmiştir.

Anahtar Kelimeler: Çocuk, Büyüme, Spor
Abstract: Objective: The aim of this study is to examine some anthropometric and physical parameters of the children participating in sports activities between the ages of 4-13 related to age and sex. Method: The research group consists of 629 children as 200 girls and 429 boys between the ages of 4-13 studying in the primary schools and training in the private sport centers. Some anthropometric measurements and hand grip, flexibility, vertical jump, standing long jump, medicine ball throw, 10-20 meters sprint and agility tests were respectively applied to the research group. Results: It is seen that boys have higher rates than girls except some age groups in the tests of standing long jump, hand grip, vertical jump and medicine ball throw applied to the research group. Similar values have been observed in children up to 6 years according to flexibility rates, but it is determined that girls have higher values from this age. When the sprint abilities are examined, it is seen that boys have lower sprint rates in many age groups. For agility ability, it is determined that boys have lower time rates in all age groups. Finally, it can be said that the anthropometric features of the children between the age of 4-13 increase depending on physical development. When examining the motoric features, it is seen that the development of girls and boys is similar up to 10 years depending on age development. However, boys show more development than girls in the areas requiring strength, speed and agility depending on muscle structure after 10 years. Conclusion: As a result, it was determined that some parameters increase depending on age and gender.

Key Words: Child, Growth, Sports

Doi: $10.17363 / S S T B .2017 .4 .1$

(1) Corresponding Author: Gökhan DELICEOĞLU, 2Kırıkkale University, Faculty of Sport Science, Kırıkale / Turkey, deliceoglugokhan@kku.edu.tr, Received: 03.09.2017, Accepted: 13.12.2017, Type ofarticle (Research -Application) Conflict of Interest: None / "Yes Ethics Committee" "Kurlkkale University, Clinical Research Ethics Committee, Issue:03 Date: 29.06.2012 


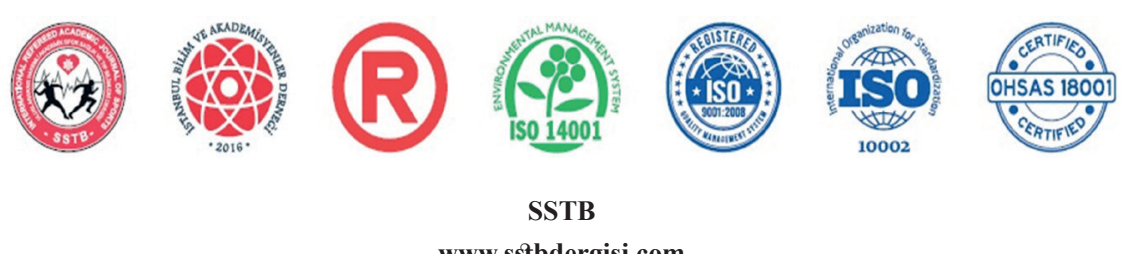

www.sstbdergisi.com

International Refereed Academic Journal of Sports, Health and Medical Sciences

October - November - December Issue 25 Autumn Winter Season Year: 2017

JEL CODE: M0-M10-M19-M50 ID:357 K:451

ISSN Print: 2146-8508 Online 2147-1711

(ISO 18001-OH-0090-13001706 / ISO 14001-EM-0090-13001706 / ISO 9001-QM-0090-13001706 / ISO 10002-CM-0090-13001706)

(TRADEMARK)

(2015/04315- 2015-GE-18972)

\section{INTRODUCTION}

One of the fundamental aims of communities is to educate healthy individuals in physical and spiritual terms. Since all the development of the child is closely related to physical development, attention in contemporary countries has been directed towards childhood sports events (Mengütay, 2005: 72).

Sports should be in the early years of the child's life because they will play an important role in cognitive development and socialization in the child's growth, maturation (Muratl1, 1997:14). By considering the versatility of children in the stages of growth and development, it is the beginning of the most frequently asked questions in sports circles and in the world of science in the following years (Açıkada, 2004:16).

The research has revealed the necessity of starting sports activities in childhood in order to achieve the expected success in sports. In this regard, developed countries focus on the activities of childhood sports. Because children's trainings have a unique set of features (Mengütay, 1999:72).

The norms of physical fitness for children, in general, assess the levels of physical fitness for children and write prescriptions for exercise and activity programmes and to supervise or observe the changes in physical fitness over time. It can also be used to identify the individual or groups' physical fitness status. However, the norms cannot be used to test success in competitions and the success of any sporting behaviour. However, the fundamental norms of the population play an active role in interpreting the physical suitability of individual and groups. These norms are always considered a critical material in controlling and defining the physical fitness changes of the group it represents (Ross et al. 1985:1046).

Ringenbach and Amazeen, (2005) stated that "An athlete with good coordination can perform more effectively for longer periods. He can perform better and longer because he is less likely to suffer from muscle weakness while performing the movements" (Suna et all., 2016: 14).

The growth and development processes of children show individual differences. The expected development by the age of the calendar is known to be early in some children and late in some children. When it comes to sports, the conflict between children's calendar age and biological age has been subject to scientific research in different aspects (Mirwald, 2002: 689).

Kraemer and Fleck, (2005) mention that there are several factors affecting growth and development, one of which is gender. In addition to some differences in the growth and deve- 


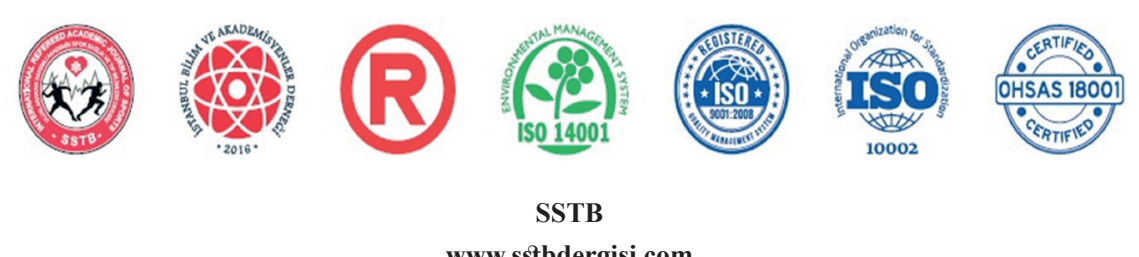

www.sstbdergisi.com

International Refereed Academic Journal of Sports, Health and Medical Sciences

October - November - December Issue 25 Autumn Winter Season Year: 2017

JEL CODE: M0-M10-M19-M50 ID:357 K:451

ISSN Print: 2146-8508 Online 2147-1711

(ISO 18001-OH-0090-13001706 / ISO 14001-EM-0090-13001706 / ISO 9001-QM-0090-13001706 / ISO 10002-CM-0090-13001706)

(TRADEMARK)

(2015/04315- 2015-GE-18972)

lopment processes related to gender, these girls are known to develop men in various areas earlier (Yaman \& Zorba, 2016: 94).

In this regard, the purpose of the research is to examine some of the anthropometric and physical parameters of children participating in sports in the 4-13 age range in the province of Ankara by age and gender.

\section{METHOD}

\section{Research group}

The research group consist of girls and boys in the 4-13 age range in Ankara which is continuing to study at different times in the Special Sports Center. Under the cross-sectional screening model, some anthropometric and physical tests were applied on the evaluation of physical suitability. The research group, which is registered in the Private Sports center, continues to be a one year and over sports multi-branch education system 4-13 age group (Group of Girls; $\mathrm{N}_{4 \text { age }}=9 ; \mathrm{N}_{5 \text { age }}=28$, $\mathrm{N}_{6 \text { age }}=20, \mathrm{~N}_{7 \text { age }}=36, \mathrm{~N}_{8 \text { age }}=31, \mathrm{~N}_{9 \text { age }}=28, \mathrm{~N}_{10}$ age $=14, \mathrm{~N}_{11 \text { age }}=20, \mathrm{~N}_{12 \text { age }}=6, \mathrm{~N}_{13 \text { age }}=8$; Male group; $\mathrm{N}_{4 \text { age }}=19, \mathrm{~N}_{5 \text { age }}=58, \mathrm{~N}_{6}$ age $=44, \mathrm{~N}_{7}$ age $=81, \mathrm{~N}_{8 \text { age }}=68, \mathrm{~N}_{9 \text { age }}=55, \mathrm{~N}_{10 \text { age }}=32, \mathrm{~N}_{11}$ age $=41, \mathrm{~N}_{12 \text { age }}=14, \mathrm{~N}_{13 \text { age }}=17$ ) Total 629 children (200 girls and 429 males) have formed.

The research group's 1-year multi-skill movement program has been conducted in different training branches, up to 4 days a week, and 1.5 hours a day. Course contents are aimed at developing basic skills specific to branches. The distribution of branches and activities (fitness, educational games, skill coordination, gymnastics, swimming, tennis, badminton, basketball, handball, football, volleyball and table tennis) varies according to age groups.

With the consent form organized by the Ethics committee, the parents permitted their children to participate in the test and still formed a research group of children who continued to study in an institution. In order to carry out the research, 29.06.2012 dated and 12/08 numbered Kirıkkale University Ethics Committee was approved.

\section{Data Collection Tools}

Length and body weight measurement applied to the research group, was $0.01 \mathrm{~kg}$ and 0.01 $\mathrm{m}$. In the sensitivity of stadiometer, Tanita device for the percentage of body fat, reaching the reach table for flexibility measurement $( \pm 1 \mathrm{~mm})$, for speed and quick measurements Newtest 2000 Brand Fotosel ( $\pm 0.01 \mathrm{sn})$, the meter for long jump measurement with the specified matte, vertical jump measurement for the "Bosco Contac mat" $( \pm 0.001 \mathrm{sec})$ and the Takei brand hand dynamometer for hand grip force were used. 


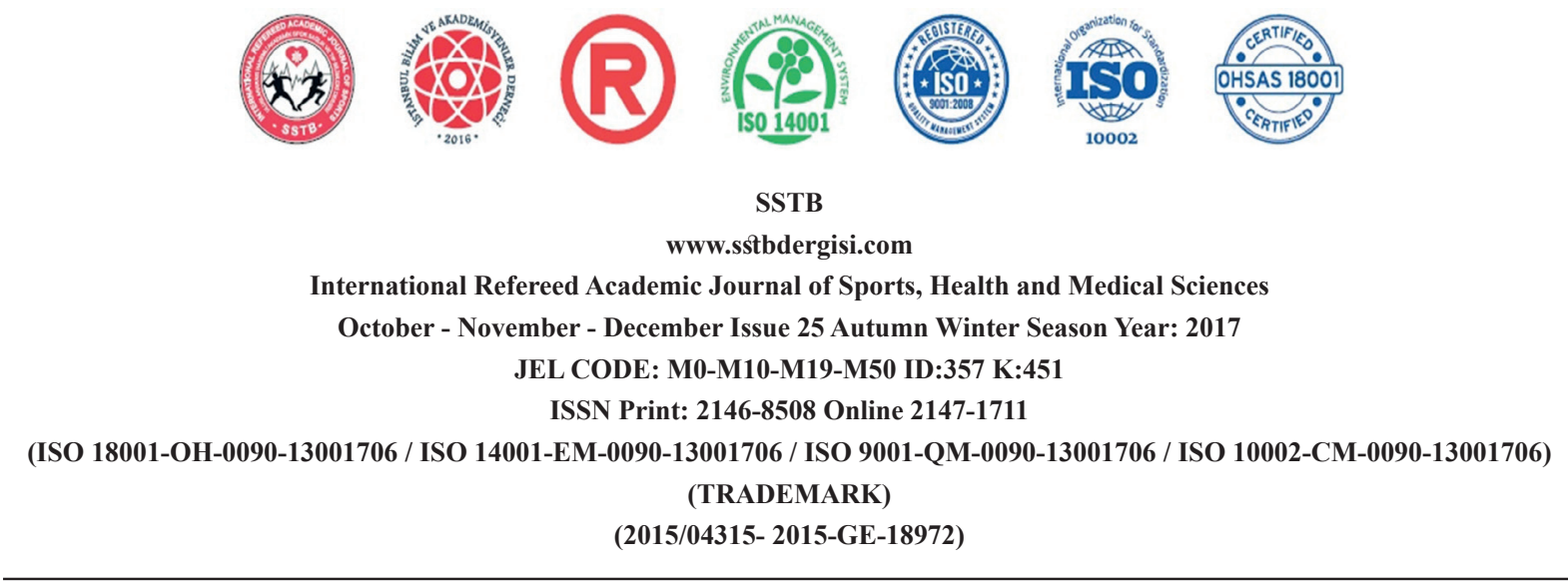

from the finish line was left as a stop distance. Starting from the exit line 10. and 20. At the beginning and end and intermediate phototorrents $(10 \mathrm{~m})$ are available in the meter. Two trials were made and adequate rest was achieved. Best recorded rating (Chu, 1996: 27).

Vertical jump measurement: Bosco mat was used in vertical jump measurement. The athlete was asked to wait for his hands on the floor. After jumping in the air, knees, calves and ankles were stretched to the fingertips and then landed on the heels (Tyson, 2004: 52).

Long jump measurement: the subject, from the back of the starting line on the ground, the feet are open at the shoulder width, with the help of the arms bent from the double foot knees, using the maximal force in a linear direction to reach the farthest point Jumped. The distance between the starting line and the track that the athlete left closest to the line was recorded in meters. The Test was repeated twice and the higher value was based (Chu, 1996: 63 ).

Flexibility measurement: The subject sits on the floor with a bare foot base and reaches the test table. The body (waist and hips) leaned forward and reached the front as far as the hands could reach the front of the body without bending the knees. Attempted to stay at the farthest point. The Test was repeated twice and the higher value was recorded (Mackenzie, 2005: 14).

Hand Grip strength measurement: The Holtain brand hand dynamometer is adjusted according to the hand size of the test, the subject's elbow without bending the lever to a straight and shoulder 10-15 angles to the side of the hand while trying to squeeze as much dynamometer as possible. The best performance was determined after 4 attempts with both hands of the subject. The dynamometer was reset after each attempt, and performance was best evaluated (Pekel et al. 2006: 299).

Health ball throwing test: The test measures the rapid force of flexser muscles in the shoulder circumference and abdomen. The feet of the subject must be parallel to each other, the face is taken forward with a constant distance of $2 \mathrm{~kg}$ of health ball, and the force to take back the arms. Then the ball with the maximal power is laid forward, with double hand. The distance between the ground and the front foot of the health ball was measured. The result was recorded (Mackenzie, 2005: 14).

Agility test: The pro-agility Agile test area, also known as the 20-yard running test, is determined by placing markers to the left and right of 5 yards $(4,57 \mathrm{~m})$ of the starting line. The Photocel gate was placed on the starting 


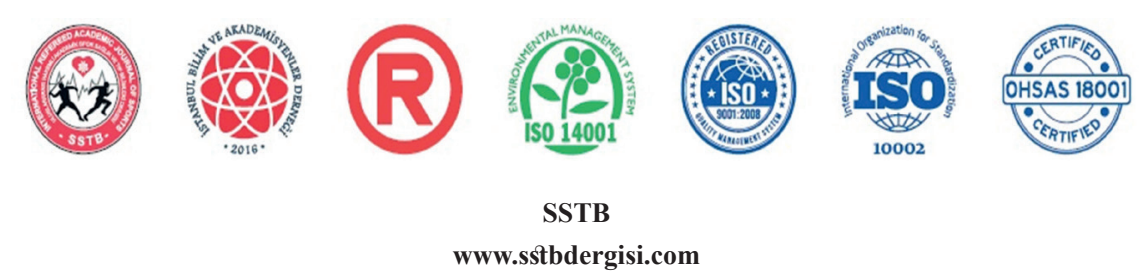

International Refereed Academic Journal of Sports, Health and Medical Sciences

October - November - December Issue 25 Autumn Winter Season Year: 2017

JEL CODE: M0-M10-M19-M50 ID:357 K:451

ISSN Print: 2146-8508 Online 2147-1711

(ISO 18001-OH-0090-13001706 / ISO 14001-EM-0090-13001706 / ISO 9001-QM-0090-13001706 / ISO 10002-CM-0090-13001706)

(TRADEMARK)

(2015/04315- 2015-GE-18972)

Table 2. BFP (\%) of Children by Age Average Values for Parameters

\begin{tabular}{lllllllllll}
\hline Girls & 4 Age & 5 Age & 6 Age & 7 Age & 8 Age & 9 Age & 10 Age & 11 Age & 12 Age & 13 Age \\
\hline Mean & 14,23 & 20,37 & 22,27 & 26,33 & 27,48 & 29,63 & 27,44 & 32,66 & 32,38 & 29,25 \\
\hline S.D & 7,33 & 11,15 & 10,54 & 11,48 & 6,92 & 7,84 & 10,51 & 9,68 & 9,87 & 12,5 \\
\hline Boys & 4 Age & 5 Age & 6 Age & $\mathbf{7}$ Age & 8 Age & 9 Age & $\mathbf{1 0}$ Age & 11 Age & 12 Age & 13 Age \\
\hline Mean & 10,84 & 14,16 & 18,38 & 21,45 & 19,21 & 20,54 & 30,17 & 27,74 & 33,05 & 34,49 \\
\hline S.D & 6,77 & 5,75 & 9,34 & 9,31 & 9,23 & 8,35 & 10,58 & 10,92 & 15,24 & 15,52 \\
\hline
\end{tabular}

When Table 2 is examined, the group of children aged 10,12 and 13 years of age, the BFP averages of boys and girls in other age groups where children are more than the BFP averages of female children BFP averages of male children's BFP averages.

The average values for the age-by-length parameters of the children who comprise the research group are given in Table 3 .

Table 3. Average Values for Children's Age-Relative Length (cm) Parameters

\begin{tabular}{lllllllllll}
\hline Girls & 4 Age & 5 Age & 6 Age & 7 Age & 8 Age & 9 Age & 10 Age & 11 Age & 12 Age & 13 Age \\
\hline Mean & 101,44 & 109,26 & 113,49 & 118,97 & 126,26 & 129,97 & 132,51 & 142,45 & 148,13 & 155,63 \\
\hline S.D & 3,28 & 8,17 & 5,21 & 10,11 & 8,17 & 8,31 & 8,14 & 8,6 & 5,19 & 6,73 \\
\hline Boys & 4 Age & 5 Age & 6 Age & $\mathbf{7}$ Age & $\mathbf{8}$ Age & 9 Age & 10 Age & 11 Age & 12 Age & 13 Age \\
\hline Mean & 107,07 & 108,81 & 114,74 & 120,14 & 124,21 & 131,37 & 136,51 & 143,67 & 150,04 & 155,46 \\
\hline S.D & 10,41 & 6,46 & 6,51 & 7,51 & 8,54 & 5,58 & 6,93 & 7,12 & 11,21 & 11,96 \\
\hline
\end{tabular}

When examining the Table 3 , the 5 and 8 years of age girls children with the average length of the height of the boys in other age groups higher than the average of the height of the boys' length of the male athletes.
The average values for long jump parameters are given in Table 4 by the age of the children who make up the research group. 


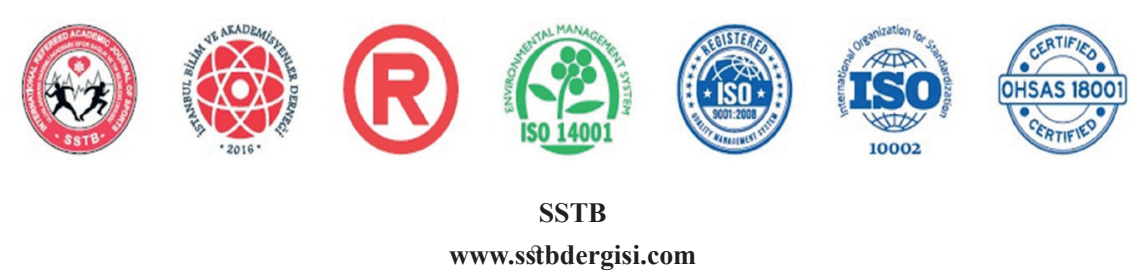

International Refereed Academic Journal of Sports, Health and Medical Sciences October - November - December Issue 25 Autumn Winter Season Year: 2017

JEL CODE: M0-M10-M19-M50 ID:357 K:451

ISSN Print: 2146-8508 Online 2147-1711

(ISO 18001-OH-0090-13001706 / ISO 14001-EM-0090-13001706 / ISO 9001-QM-0090-13001706 / ISO 10002-CM-0090-13001706) (TRADEMARK)

(2015/04315- 2015-GE-18972)

Table 4. Average Values for Long Jump (cm) Parameters of Children by Age

\begin{tabular}{lllllllllll}
\hline Girls & 4 Age & 5 Age & 6 Age & 7 Age & 8 Age & 9 Age & 10 Age & 11 Age & 12 Age & 13 Age \\
\hline Mean & 58,88 & 72,5 & 79,95 & 85,08 & 98,06 & 98,47 & 101,5 & 119,55 & 105,5 & 156,88 \\
\hline S.D & 14,41 & 20,12 & 20,75 & 26,68 & 19,07 & 28,73 & 23,64 & 25,1 & 16,97 & 38,71 \\
\hline Boys & 4 Age & 5 Age & 6 Age & 7 Age & 8 Age & 9 Age & 10 Age & 11 Age & 12 Age & 13 Age \\
\hline Mean & 62,5 & 70,78 & 81,85 & 91,91 & 104,77 & 114,67 & 117,89 & 124,62 & 125,64 & 140,6 \\
\hline S.D & 29,96 & 19,36 & 22,14 & 26,8 & 26,86 & 23,72 & 24,24 & 31,02 & 19,07 & 33,17 \\
\hline
\end{tabular}

When examining the Table 4, the research group consists of 5 and 13 age girls who have long jump values by stopping boys children from long jump values, while other age groups are better at stopping boys' long jump va- lues while the girls It is better than the values of children.

The average values for the hand grip strength parameters of the children who comprise the research group are given in Table 5.

Table 5. Average Values for The Parameters of Hand Grip (kg) According to Age of

\section{Children}

\begin{tabular}{lllllllllll}
\hline Girls & 4 Age & 5 Age & 6 Age & 7 Age & 8 Age & 9 Age & 10 Age & 11 Age & 12 Age & 13 Age \\
\hline Mean & 7,1 & 7,71 & 7,06 & 7,59 & 9,6 & 9,97 & 10,84 & 13,19 & 15,38 & 19,24 \\
\hline S.D & 2,97 & 2,96 & 1,85 & 3,25 & 3,12 & 2,9 & 4,38 & 4,46 & 1,72 & 7,71 \\
\hline Boys & 4 Age & 5 Age & 6 Age & $\mathbf{7}$ Age & $\mathbf{8}$ Age & 9 Age & $\mathbf{1 0}$ Age & 11 Age & 12 Age & 13 Age \\
\hline Mean & 7,32 & 7,59 & 7,83 & 8,87 & 9,24 & 11,13 & 11,36 & 14,04 & 17,93 & 20,92 \\
\hline S.D & 2,43 & 1,94 & 2,21 & 3,14 & 3,29 & 3,27 & 3,6 & 4,5 & 5,51 & 9,74 \\
\hline
\end{tabular}

When examining the table 5 , the study group of 5 and 8 years of age girls' hand grip strength values are better than the values of male children's hand grip force, whereas ot- her age groups boys children's hand grip values better than girsl values.

The average values for the vertical jump parameters of the children that comprise the research group are given in Table 6 . 


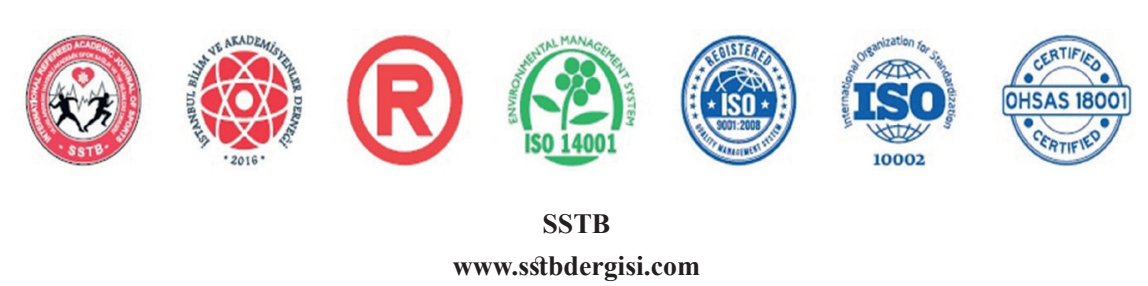

International Refereed Academic Journal of Sports, Health and Medical Sciences

October - November - December Issue 25 Autumn Winter Season Year: 2017

JEL CODE: M0-M10-M19-M50 ID:357 K:451

ISSN Print: 2146-8508 Online 2147-1711

(ISO 18001-OH-0090-13001706 / ISO 14001-EM-0090-13001706 / ISO 9001-QM-0090-13001706 / ISO 10002-CM-0090-13001706) (TRADEMARK)

(2015/04315- 2015-GE-18972)

Table 6. Average Values for Vertical Jump (cm) Parameters of Children by Age

\begin{tabular}{lllllllllll}
\hline Girls & 4 Age & 5 Age & 6 Age & 7 Age & 8 Age & 9 Age & 10 Age & 11 Age & 12 Age & 13 Age \\
\hline Mean & 9,57 & 14,08 & 15,49 & 14,15 & 16,43 & 16,77 & 16,68 & 17,78 & 15,17 & 22,54 \\
\hline S.D & 5,44 & 4,93 & 4,58 & 4,8 & 4,44 & 5,62 & 3,81 & 6,09 & 1,94 & 2,96 \\
\hline Boys & 4 Age & 5 Age & 6 Age & 7 Age & 8 Age & 9 Age & 10 Age & 11 Age & 12 Age & 13 Age \\
\hline Mean & 11,2 & 13,72 & 13,69 & 14,62 & 17,52 & 17,26 & 15,82 & 18,19 & 18,92 & 21,36 \\
\hline S.D & 6,66 & 5,3 & 5,22 & 5,16 & 4,49 & 5,07 & 5,01 & 4,87 & 5,47 & 4,97 \\
\hline
\end{tabular}

When examining the Table 6 , the children of $5,6,10$ and 13 age girls, vertical jump values are higher than the vertical jump values of male children, whereas other age groups have children's vertical jump values higher than their values.

The average values of the children who comprise the research group in relation to the age of flexibility parameters are given in Table 7.

Table 7. Average Values for The Flexibility of Children by Age $(\mathrm{cm})$ Parameters

\begin{tabular}{lllllllllll}
\hline Girls & 4 Age & 5 Age & 6 Age & 7 Age & 8 Age & 9 Age & 10 Age & 11 Age & 12 Age & 13 Age \\
\hline Mean & 24,04 & 23,62 & 26,73 & 25,21 & 26,87 & 24,04 & 27,03 & 20,44 & 28,92 & 26,67 \\
\hline S.D & 4,69 & 5,92 & 4,77 & 5,76 & 6,02 & 7,1 & 7,08 & 8,41 & 6,74 & 7,84 \\
\hline Boys & 4 Age & 5 Age & 6 Age & 7 Age & 8 Age & 9 Age & 10 Age & 11 Age & 12 Age & 13 Age \\
\hline Mean & 24,38 & 23,09 & 24,17 & 23,62 & 21,79 & 23,26 & 18,69 & 18,33 & 17,58 & 15,5 \\
\hline S.D & 6,16 & 5,7 & 4,72 & 5,39 & 6,36 & 7,62 & 6,31 & 7,99 & 8,66 & 6,9 \\
\hline
\end{tabular}

When examined in Table 7, the 4-5 age of boys and girls who comprise the research group, the flexibility values are similar, and the flexibility values of girls in other age groups were better than the values of male children's flexibility.

The average values for the health ball throwing parameters of the children who comprise the research group are given in table 8 . 
(ISO 18001-OH-0090-13001706 / ISO 14001-EM-0090-13001706 / ISO 9001-QM-0090-13001706 / ISO 10002-CM-0090-13001706) (TRADEMARK)

(2015/04315- 2015-GE-18972)

Table 8. Average Values for Health Ball Throwing (m) Parameters by Age of Children

\begin{tabular}{lllllllllll}
\hline Girls & 4 Age & 5 Age & 6 Age & 7 Age & 8 Age & 9 Age & 10 Age & 11 Age & 12 Age & 13 Age \\
\hline Mean & 1,86 & 1,79 & 1,95 & 2,23 & 2,8 & 2,91 & 3,18 & 3,77 & 3,72 & 4,88 \\
\hline S.D & 1,96 & 0,76 & 0,56 & 0,67 & 1,23 & 0,85 & 0,83 & 0,96 & 0,72 & 1,12 \\
\hline Boys & 4 Age & 5 Age & 6 Age & 7 Age & 8 Age & 9 Age & 10 Age & 11 Age & 12 Age & 13 Age \\
\hline Mean & 1,6 & 1,94 & 2,15 & 2,69 & 2,8 & 3,31 & 3,42 & 4,25 & 4,54 & 5,15 \\
\hline S.D & 0,94 & 0,82 & 0,95 & 1,08 & 0,7 & 0,87 & 0,85 & 1,44 & 0,66 & 1,85 \\
\hline
\end{tabular}

When examining Table 8 the study group of 4-year-olds girls, health ball throwing values are better than the values of the male children's health ball throwing, while other age groups of girls' health ball throwing values were better than boys throwing values.

Table 9. Average Values for 10 meter Speed (sec) Parameters Based on Age of Children

\begin{tabular}{lllllllllll}
\hline Girls & $\mathbf{4}$ & $\mathbf{5}$ Age & $\mathbf{6}$ Age & $\mathbf{7}$ Age & $\mathbf{8}$ Age & $\mathbf{9}$ Age & 10 Age & 11 Age & 12 Age & 13 Age \\
\hline Mean & 3,69 & 3,2 & 3,31 & 3,05 & 2,7 & 2,73 & 2,73 & 2,6 & 2,64 & 2,31 \\
\hline S.D & 0,44 & 0,44 & 0,71 & 0,39 & 0,24 & 0,33 & 0,27 & 0,18 & 0,22 & 0,13 \\
\hline Boys & $\mathbf{4}$ & $\mathbf{5}$ Age & $\mathbf{6}$ Age & $\mathbf{7}$ Age & $\mathbf{8}$ Age & $\mathbf{9}$ Age & $\mathbf{1 0}$ Age & $\mathbf{1 1}$ Age & 12 Age & 13 Age \\
\hline Mean & 3,47 & 3,28 & 3,12 & 2,98 & 2,75 & 2,71 & 2,64 & 2,45 & 2,4 & 2,47 \\
\hline S.D & 0,57 & 0,35 & 0,34 & 0,52 & 0,24 & 0,43 & 0,3 & 0,31 & 0,22 & 0,3 \\
\hline
\end{tabular}

When examined in Table 9, the 5, 8 and 13 age girls who participated in the research group are better than male athletes with $10 \mathrm{~m}$ speed capabilities, and other age groups are
The average values for the $10 \mathrm{~m}$ speed parameters according to the age of the children who comprise the research group are given in Table 9. 


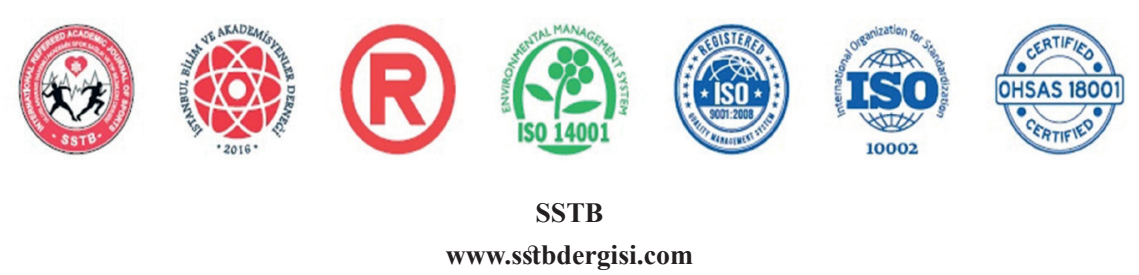

International Refereed Academic Journal of Sports, Health and Medical Sciences October - November - December Issue 25 Autumn Winter Season Year: 2017

JEL CODE: M0-M10-M19-M50 ID:357 K:451

ISSN Print: 2146-8508 Online 2147-1711

(ISO 18001-OH-0090-13001706 / ISO 14001-EM-0090-13001706 / ISO 9001-QM-0090-13001706 / ISO 10002-CM-0090-13001706) (TRADEMARK)

(2015/04315- 2015-GE-18972)

Table 10. Average Values for 20 Meter Speed (Sec) Capabilities According to Children's Age

\begin{tabular}{lllllllllll}
\hline Girls & 4 Age & 5 Age & 6 Age & 7 Age & 8 Age & 9 Age & 10 Age & 11 Age & 12 Age & 13 Age \\
\hline Mean & 7,21 & 6,33 & 6,3 & 5,84 & 5,12 & 4,95 & 5,08 & 4,71 & 4,77 & 4,2 \\
\hline S.D & 0,85 & 1,24 & 0,97 & 0,89 & 0,49 & 0,53 & 0,53 & 0,43 & 0,4 & 0,31 \\
\hline Boys & 4 Age & 5 Age & 6 Age & 7 Age & 8 Age & 9 Age & 10 Age & 11 Age & 12 Age & 13 Age \\
\hline Mean & 6,96 & 6,26 & 5,85 & 5,57 & 5,1 & 4,95 & 4,78 & 4,42 & 4,37 & 4,45 \\
\hline S.D & 1,21 & 0,77 & 0,88 & 0,85 & 0,57 & 0,79 & 0,68 & 0,48 & 0,48 & 0,52 \\
\hline
\end{tabular}

When the Table 10 is examined, the 13-yearold girls who participated in the research group are better than male athletes of $20 \mathrm{~m}$ speed, and in other age groups, $20 \mathrm{~m}$ speed of male children is better than girls athletes.

Table 11. Average Values for Agility (Sec) Parameters for Children's Age

\begin{tabular}{lllllllllll}
\hline Girls & 4 Age & 5 Age & 6 Age & 7 Age & 8 Age & 9 Age & 10 Age & 11 Age & 12 Age & 13 Age \\
\hline Mean & 11,67 & 8,75 & 8,64 & 7,94 & 7,21 & 7,2 & 7,15 & 6,78 & 6,89 & 5,99 \\
\hline S.D & 2,69 & 2,06 & 0,69 & 0,68 & 0,69 & 0,65 & 0,8 & 0,72 & 0,38 & 0,16 \\
\hline Boys & 4 Age & 5 Age & 6 Age & 7 Age & 8 Age & 9 Age & 10 Age & 11 Age & 12 Age & 13 Age \\
\hline Mean & 8,73 & 7,91 & 7,78 & 7,62 & 6,9 & 6,3 & 6,38 & 5,73 & 5,93 & 5,71 \\
\hline S.D & 2,8 & 2,47 & 2,03 & 1,44 & 1,37 & 1,81 & 1,5 & 1,49 & 0,69 & 1,38 \\
\hline
\end{tabular}

When examined in Table 11, it is observed that the agility values of male children in all age groups participating in the study group are better than the agility values of girls.

\section{DISCUSSION}

This section includes recommendations for results and similar studies based on findings from some of the anthropometric and physi-
The average values for the agility (sec) parameters of the children that comprise the research group are given in Table 11. cal parameters of the children who have done selected sports.

Similar studies have been analysed to monitor the physical developments of the research group and to have information about their physical structure according to the body length parameter. In a study, the average aspect value of the 10 age group 78 girls was $137,2 \pm 6,7 \mathrm{~cm}$. While the average value of 


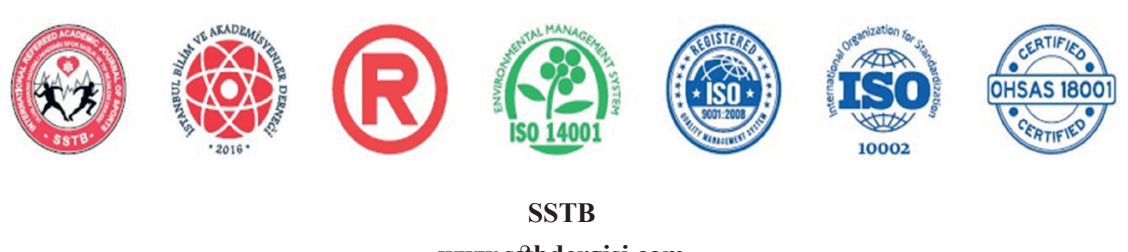

www.sstbdergisi.com

International Refereed Academic Journal of Sports, Health and Medical Sciences

October - November - December Issue 25 Autumn Winter Season Year: 2017

JEL CODE: M0-M10-M19-M50 ID:357 K:451

ISSN Print: 2146-8508 Online 2147-1711

(ISO 18001-OH-0090-13001706 / ISO 14001-EM-0090-13001706 / ISO 9001-QM-0090-13001706 / ISO 10002-CM-0090-13001706) (TRADEMARK)

(2015/04315- 2015-GE-18972)

the same age group 45 male was obtained $137,3 \pm 6,7 \mathrm{~cm} .11$ age group 97 girls in the subject of the $139,7 \pm 8,0 \mathrm{~cm}$ corresponding to the value obtained, 131 male in the subject of the same variable was determined as $139,1 \pm 6,5$ $\mathrm{cm}$. The average length of the 142 girls in the 12 -year group was $145,2 \pm 8,4 \mathrm{~cm}$. while 152 males had the same value as $144,6 \pm 7,4 \mathrm{~cm}$ (Kavak, 2006: 14).

As a result of our study, there is no difference between the lengths of girls and boys in many sources, but it shows that boys are more developed than girls, except for early development children. This is because the adolescent period of girls is thought to have been completed before men.

When the body weight parameter is examined, it is seen that the 10-11 age group is parallel with the girls in the same age group in terms of values. The 12-year-old males also show parallelism as they are at age 10 and 11 . However, in many studies, there is no apparent difference in the physical aspect of girls and men in this age group, except for early development children, the onset of 13 has shown that boys are more developed than girls. However, it is noted in various sources that the girls, which show a little more development than the physical aspect of the age of 12 . After this age, development is returned in favour of boys.
In the study of 12-14 age group children in Erzincan Province, the average 40,9 $99,17 \mathrm{~kg}$ in the center of the body weight in women aged 12 years. While, the mean districts $36,24 \pm 7,70$ $\mathrm{kg}$. In men, the center of the city averages $39,44 \pm 10,68 \mathrm{~kg}$. While, the mean districts $35,79 \pm 6,85 \mathrm{~kg}$ (Çolak \& Kaya, 2006: 33).

In our research, when the body weights are examined, there is no apparent difference between the 4-13 age group and the boys and girls, and children from 10 years old have shown more growth. After this age, it is stated in several different sources of development. As a cause of this increase, children are considered to have increased length.

When the body mass index values were examined, in a study conducted on the 12-14 age group 177 children in the province of $18,64 \pm 2,80 \mathrm{~kg} / \mathrm{m}^{2}$ in the center of Erzincan city the body mass index in women aged 12 years, the average of the districts $17,58 \pm 3,08$ $\mathrm{kg} / \mathrm{m}^{2}$, in boys whereas the center of the province was $18,11 \pm 3,21 \mathrm{~kg} / \mathrm{m}^{2}$, the average of the districts was $17,34 \pm 2,51 \mathrm{~kg} / \mathrm{m}^{2}$ (Çolak \& Kaya, 2006: 40).

Acording to result of the study, the average $18,0 \pm 2,4 \mathrm{~kg} / \mathrm{m}^{2}, 12$-year-old 69 male child of 11-year-old 21 male subjects in primary school was reached in the mean $18,9 \pm 3,5 \mathrm{~kg} / \mathrm{m}^{2}$. In the same study, the average value of the 11 -year-old 40 girl was obtained as $17,7 \pm 2,4$ 


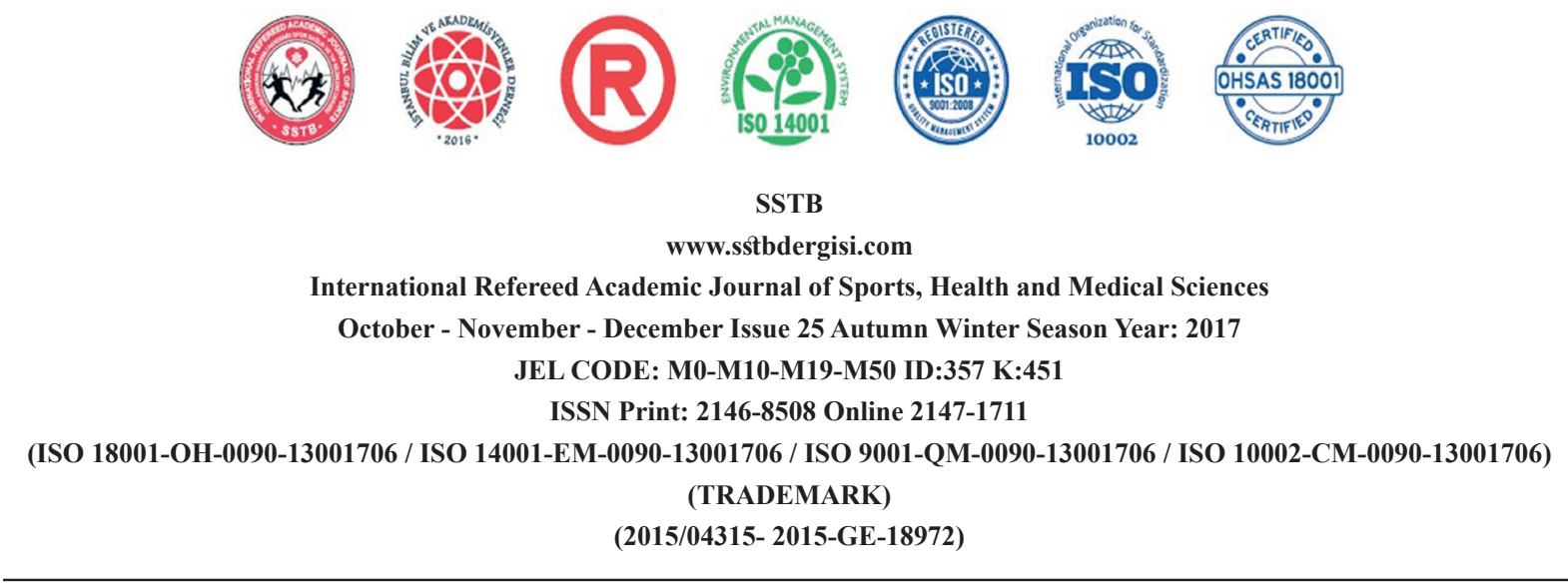

$\mathrm{kg} / \mathrm{m}^{2}$, while the average value of the 12-yearold 143 girl was $19,4 \pm 3,5 \mathrm{~kg} / \mathrm{m}^{2}$ (Bodur \& Uğuz, 2007: 21).

When the body fat percentages are examined; In a study conducted on a total of 24 male basketball players aged between 13 and 14 years of age, the percentage of the experimental group body fat was $19,54 \pm 5,44$, and the post-workout averages were determined as 16,89 $\pm 4,97$ (Erol et al. 1999: 12).

In a different study, a total of 52 male children aged between 10 and 13 years of age were $14,5 \pm 4,9$ of the average body fat percentage (Pekel et al. 2006: 308).

When the BFP and BMI are examined, the values in all age groups are not observed in a significant difference between boys and girls, but the increase in values can be said to be due to growth in height and body weight.

When the vertical jump parameter is examined, the vertical rat, which is one of the explosive indicators between the ages of 1012 and the development of physical development and performance, is parallelism in the evolution of both girls and men groups Seen. In a study, the average $24,77 \pm 5,12 \mathrm{~cm}$ on the 84 male children who do not do sports in the 10-12 age group., the minimum value is 13 $\mathrm{cm}$., and the maximum value is $40 \mathrm{~cm}$ (Bayraktar, 2013: 7).
In a different study of the 6-11 age group 776 girls, a vertical jump average of 10 age group girls, including 100 , is $29,25 \pm 5,66 \mathrm{~cm}$ while the minimum value is $16 \mathrm{~cm}$ and the maximum value is $48 \mathrm{~cm}$. The average value $31,40 \pm 5,75 \mathrm{~cm}$ was found in the 11-year-old girls who attended the 44 experiment. (Turgut \& Çetinkaya, 2006:1041).

The values obtained are parallel to the results of our research. There are no apparent differences between girls and men in vertical jump values. The vertical jump between physical development and performance development is one of the indicators of explosives, which is seen to resemble the development of men and girls. The reason for this is thought to be similar to the development of the leg strength of boys and girls.

When the values of the 10 and 11 age group girls and boys of the right hand grip strength are examined, the measurements are shown to be parallel to each other, as compared to girls, the right hand grip strength of the boys in the 12 year group increased slightly. Some sources indicate that children from the age of 10 have started to secrete hormones according to gender, and these hormones have been increased since 11 years.

In a study conducted in the 10-12 age group, the $15,7 \pm 3,1 \mathrm{~kg}$ of the right hand grip force on the 84 male child who did not do sports. 


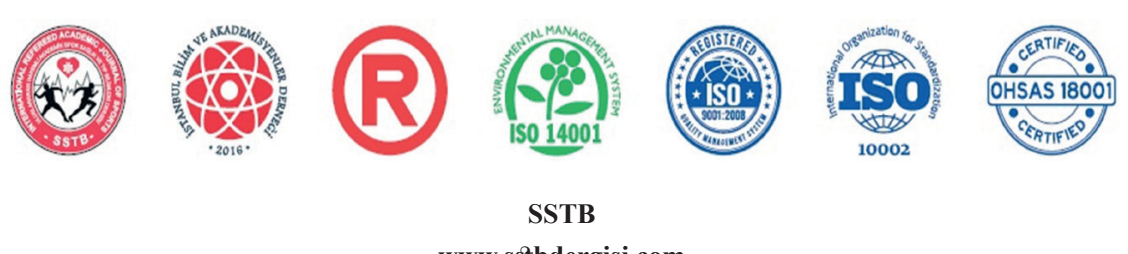

www.sstbdergisi.com

International Refereed Academic Journal of Sports, Health and Medical Sciences

October - November - December Issue 25 Autumn Winter Season Year: 2017

JEL CODE: M0-M10-M19-M50 ID:357 K:451

ISSN Print: 2146-8508 Online 2147-1711

(ISO 18001-OH-0090-13001706 / ISO 14001-EM-0090-13001706 / ISO 9001-QM-0090-13001706 / ISO 10002-CM-0090-13001706)

(TRADEMARK)

(2015/04315- 2015-GE-18972)

When you find; The minimum value is 7,9 $\mathrm{kg}$. The maximum value is $23,6 \mathrm{~kg}$ have been found. According to the research results that only the maximum value is high according to this study, we can indicate that some of the early children in the 12 age group may have high values. As we have stated earlier, some of the children with early development will have high values (Bayraktar, 2013: 6).

It is thought that the increase is linear because the movement is not a very complex movement in men and girls as a cause of this similarity.

When the long jump parameter is examined, it is stated in a variety of sources, which are determined to be one of the long-jump explosive force indicators in each age group and in which the gender growth is determined.

As a result of the study, 10 years of age group 100 girl's child, the long jump value of the average $123,81 \pm 20,15 \mathrm{~cm}$. The minimum value was $85 \mathrm{~cm}$ and the maximum value was $184 \mathrm{~cm}$ (Turgut \& Çetinkaya, 2006:1041).

Another study that can be associated with this subject is the norm standards that need to be obtained at the first stage of the choice of ability to stop the long jump value of 10 years in girls $165 \mathrm{~cm} .175 \mathrm{~cm}$ in males. He has determined $175 \mathrm{~cm}$ in girls of 11 years and 190 $\mathrm{cm}$ in males. The study supports research in 11 age group girls, while the maximum me- asurements in other groups are over 5-10\% (Biçer \& Ak11, 2005: 754).

It is thought that the increase is linear because the movement is not a very complex movement in men and girls as a cause of this similarity.

In terms of health ball throwing values, gender and age groups, we see that there is also improvement in the health ball throwing by stopping in all categories. The average value was $419,2 \pm 87,9 \mathrm{~cm}$ in the 10 -year-olds, and in the 11 age group, this value rose to $481,9 \pm 92,7 \mathrm{~cm}$. and $543,8 \pm 116,3 \mathrm{~cm}$ in 12 age group girls. The average is $471,5 \pm 85,4 \mathrm{~cm}$. In the 10 age group of males, the same variable was determined as $531,6 \pm 84,4 \mathrm{~cm}$ in the 11 age group, the 12 age group was evaluated as $579,1 \pm 113,9 \mathrm{~cm}$ in males.

According to a study, one of the eight criteria that Bulgarian children should achieve in the first election stage is a health ball throwing of $700 \mathrm{~cm}$ in males of 10 years. The desired value in the same age group girls is $650 \mathrm{~cm}$. 11 age group girls for the male children, the value specified as $700 \mathrm{~cm}$ is determined to be $750 \mathrm{~cm}$ (Jonston et al. 2003: 627).

The results of this research demonstrate the parallels with the results of our research. The long jump, the right hand grip force and the health ball throwing values from the force indicators do not show significant differences 


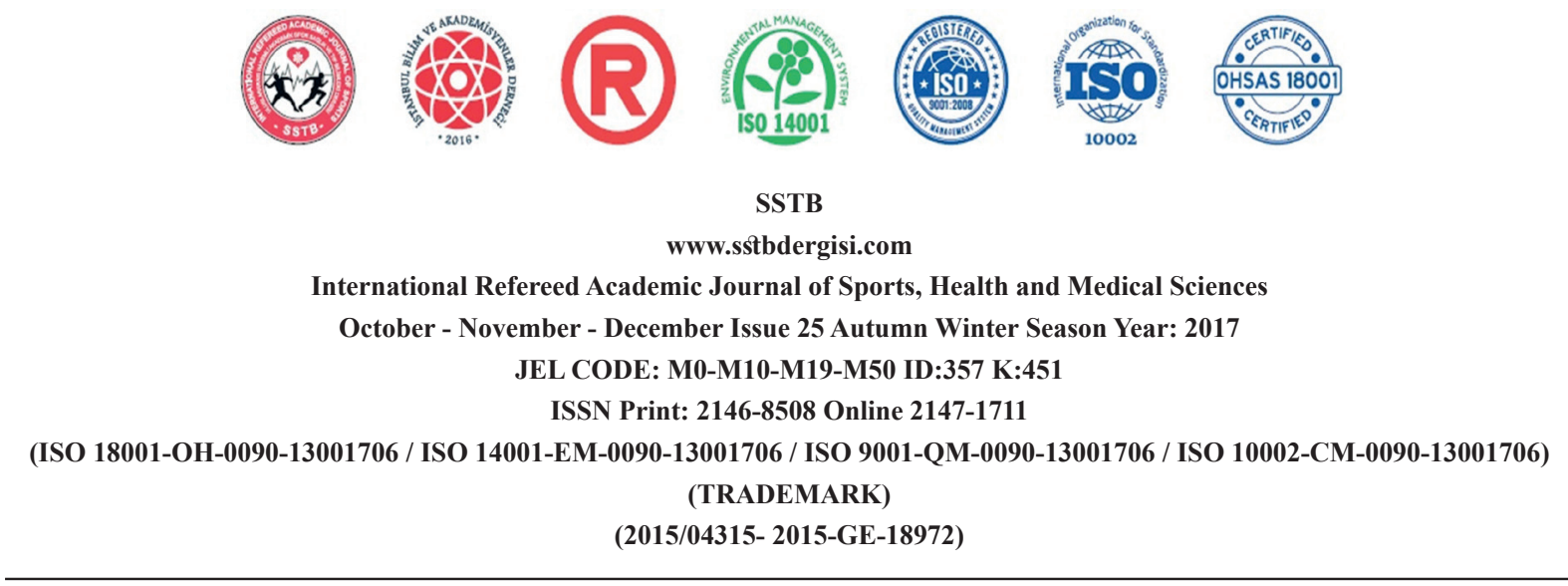

in the age of 10 , but after the age of 10 , men have shown more improvement depending on muscle development. This is due to the fact that the muscle structure of men is more than girls.

When the flexibility parameter is examined, the average value determined as $18,7 \pm 5,2 \mathrm{~cm}$ in the 10 age group girls was determined as $20,0 \pm 6,4 \mathrm{~cm}$ in 12 age group girls. The average value of $17,3 \pm 5,4 \mathrm{~cm}$ in males of 10 age group was determined as $18,4 \pm 5,6 \mathrm{~cm}$ in males of 12 years. As a result of the research, 10 years of age group the average $24,98 \pm 6,39$ $\mathrm{cm}$ in the value of flexibility on the girl; The minimum value was $9 \mathrm{~cm}$ and the maximum value was $41 \mathrm{~cm}$. The average value of the 11 age group of 44 subjects was $26,57 \pm 7,68 \mathrm{~cm}$ while the minimum value was $5 \mathrm{~cm}$ and the maximum value was $41 \mathrm{~cm}$ (Turgut \& Çetinkaya, 2006).

In a study, the new norm under the name "New standards for Fitness measurements (NCYFS)" is also the maximum value in men aged 10 to $38,2 \mathrm{~cm}$, the value of $75 \%$ is $29,3 \mathrm{~cm}, 50 \%$ value is $26,8 \mathrm{~cm}$ and $25 \%$ is determined as $21,7 \mathrm{~cm}$. The parallelism of the norms in the 11 and 12 age group is remarkable. In the men of these age groups, the value of $75 \%$ corresponds to the maximum value set to $39,5 \mathrm{~cm} .30,6 \mathrm{~cm}$. $50 \%$ is $20 \mathrm{~m}$ (Ross et al., 2007: 1056).
When the flexibility parameters are examined, the flexibility of up to 7 years of age is observed to develop more in girls, depending on muscle and body development. It is thought that the flexibility in performance with age declines less than men in girls because of the fact that girls do not decrease the performance of men depending on age.

When the speed is examined, an average of $20 \mathrm{~m}$ speed run is $4,63 \pm 0,37 \mathrm{sec}$ in a study conducted on the 10-year-old group of 100 girls. When you find; the minimum value is $4,05 \mathrm{sec}$ and the maximum value is $5,72 \mathrm{sec}$ was measured. The average value 4,22 $\pm 0,38$ sec in the 11-year-old girls consisting of 44 subjects. When determining the minimum value is $3,70 \mathrm{sec}$, the maximum value is $5,35 \mathrm{sec}$ and also 4,38 $\pm 0,41 \mathrm{sn}$. in 10-year-old girls in the $20 \mathrm{~m}$. speed run, in which the development of all age groups and gender is still ongoing 4,23 $\pm 0,29 \mathrm{sec}$ in 12 age group women obtained. $4,17 \pm 0,34 \mathrm{sec}$ in males of the age group 10, 4,08 $\pm 0,23 \mathrm{sec}$ in 12-year-old males (Turgut \& Çetinkaya, 2006: 1041).

When the agility and speed capabilities are examined, there are no apparent differences between the groups until the age of 9 , while the males are more developed after the 10year group. The reason for this is that after the age of 10 , the muscle structures of men are more developed in various sources. 


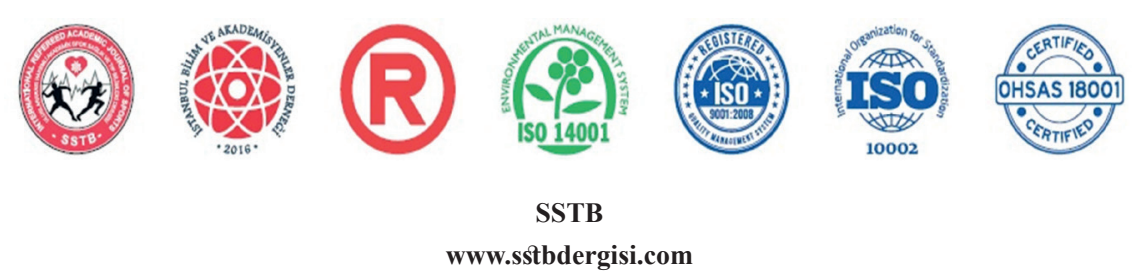

International Refereed Academic Journal of Sports, Health and Medical Sciences October - November - December Issue 25 Autumn Winter Season Year: 2017

JEL CODE: M0-M10-M19-M50 ID:357 K:451

ISSN Print: 2146-8508 Online 2147-1711

(ISO 18001-OH-0090-13001706 / ISO 14001-EM-0090-13001706 / ISO 9001-QM-0090-13001706 / ISO 10002-CM-0090-13001706) (TRADEMARK)

(2015/04315- 2015-GE-18972)

KAVAK, V., (2006). The Determination of Subcutaneous Body Fat Percentage by Measuring Skinfold Thickness in Teenagers in Turkey. International Journal of Sport Nutrition and Exercise, 16 (1): 14-22

MACKENIZE, B., (2005). 101 Performance Evaluation Tests. $1^{\text {st }}$ ed.London: Electric Word, p. 14

MENGÜTAY, S., (1999). Movement Development And Sports in Pre And Primary School Children. 1. Bask1. Ankara: Tütibay Ltd.Şti. p.72

MENGÜTAY, S., (2005). Movement Development And Sports in Child. 1. Bask1. Ankara: Morpa Yayın, P.25-27

MIRWALD, R. L., BAXTER-JONES, A. D. G., BAILEY, D. A, BEUNEN, G. P., (2002). An assessment of maturity from anthropometric measurements. Medicine and Science in Sports and Exercise, 34(4), 689-94

MURATLI, S., (1997). Çocuk ve Spor. 1. Baskı. Ankara: Bağırgan Yayım evi, p. 14-24

PEKEL, H.A., BAĞCI, E., ATALAY, N., ONAY, M., SERDAR, Ş., PEPE, H., (2006). Physical Fitness Test Results in Children with Evaluation of the Relationship Between Anthropometric Cha- racteristics]. Kastamonu Eğitim Dergisi, 14(1):299-308

POSKITT, E.M., (1995). Defining childhood obesity: the relative body mass index (BMI). European Childhood Obesity group. Acta Paediatr, 84(8):961-963

ROSS, C.F., DHARIA, R., HERRING, S.W., HYLANDER, W.L., LIU, Z.J., RAFFERTY, K.L., RAVOSA, M.J., WILLIAMS, S.H., (2007). Modulation of mandibular loading and bite force in mammals during mastication. Journal of Experimental Biology, 210 (6):1046

ROSS, J.G., DOTSON, C.O., GILLBERT, G.G., KATZ, S.J., (1985). The National Children and Youth Fitness Study: New standards for fitness measurement. JOHPERD. 56(1):20-24

SUNA, G., BEYLEROĞLU, M., ALP, M., YALÇIN, S., (2016). Investigating The Effects Of Coordination Trainings On Velocity, Balance And Agility Features Of Tennis Kids. SSTB International Refereed Academic Journal of Sports, (20), 1323; Doi: 10.17363/SSTB.20162022364

TURGUT, A., ÇETINKAYA, V., (2006). Determination of Some of the girls in the 6-11 at age group children' Motoric Functions. Muğla: 9. Uluslararası Spor Bilimleri Kongresi. 3-5 Kasım 


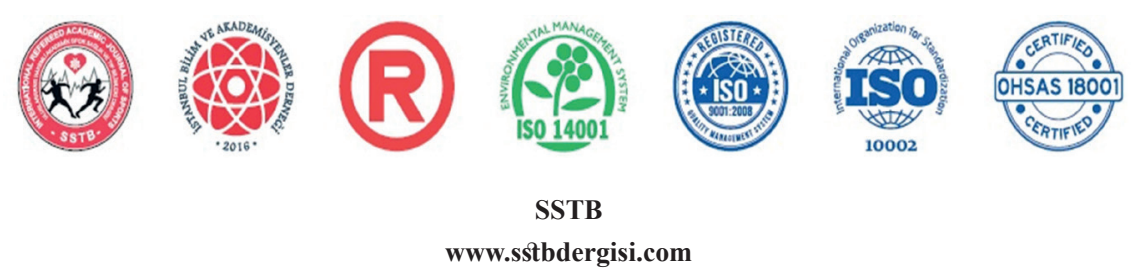

International Refereed Academic Journal of Sports, Health and Medical Sciences

October - November - December Issue 25 Autumn Winter Season Year: 2017

JEL CODE: M0-M10-M19-M50 ID:357 K:451

ISSN Print: 2146-8508 Online 2147-1711

(ISO 18001-OH-0090-13001706 / ISO 14001-EM-0090-13001706 / ISO 9001-QM-0090-13001706 / ISO 10002-CM-0090-13001706) (TRADEMARK)

(2015/04315- 2015-GE-18972)

TYSON, A., COOK, B. (2004). Jumpmetrics. $1^{\text {st }}$ ed. USA: Human Kinetics, p. 52

YAMAN, N., ZORBA, E., (2016). The Effect

Of Biological Maturity On Gender- Related Motor Skills At Talent Selection That Is Made According To Chronological Age
In Sports. SSTB International Refereed Academic Journal of Sports, (21), 94108; doi:10.17363/SSTB.20162124011

ZORBA, E., (1999). Physical Fitness and Sports For All. Muğla: Gazi Kitapevi, p, 337 